\title{
Overwintering insect (Arthropoda: Insecta) biodiversity in pistachio orchards of the Middle Euphrates Valley, Turkey
}

\section{Orta Fırat Vadisinde antepfıstığı bahçelerinde kışlayan böcek (Arthropoda: Insecta) biyoçeşitliliği}

\author{
Yeliz SABUNCU1 ${ }^{\text {iD }}$, Mehmet MAMAY2*iD, İnanç ÖZGEN³ ${ }^{3}$ \\ ${ }^{1,2}$ Plant Protection Department, Agricultural Faculty, Harran University, Şanlıurfa, Turkey \\ ${ }^{3}$ Bioengineering Department, Engineering Faculty, Fırat University, Elazığ, Turkey \\ ${ }^{1}$ https://orcid.org/0000-0001-9713-7617; ${ }^{2}$ https://orcid.org/0000-0003-3723-5228; ${ }^{3}$ https://orcid.org/0000-0003-1742-9324
}

To cite this article:

Sabuncu, Y., Mamay, M. \& Özgen, i. (2021). Overwintering insect (Arthropoda: Insecta) biodiversity in pistachio orchards of the Middle Euphrates Valley, Turkey. Harran Tarım ve Gıda Bilimleri Dergisi, 25(2): 185192.

DOI: $10.29050 /$ harranziraat.884529

*Address for Correspondence: Mehmet MAMAY e-mail:

mehmetmamay@hotmail.com

Received Date: 22.02.2021

Accepted Date: 07.05.2021

(C) Copyright 2018 by Harran University Faculty of Agriculture. Available on-line at www.dergipark.gov.tr/harranziraat

\section{ABSTRACT}

This study was conducted to determine the overwintering insect biodiversity in pistachio orchards of the Middle Euphrates Valley, Turkey during 2017 and 2018 by artificial overwintering shelters. Artificial overwintering shelters were established in five pistachio orchards in Şehirbağı, Karabaş, Meyanca, Baraj and Ekenek locations. Ten trees were selected within each orchard and five of these were covered with a burlap sack and the rest were covered with corrugated cardboard through September and January. Twenty insect species belonging to15 families and 4 orders were recorded from the studied orchards. These recorded species were; Oenopia conglobata (Linnaeus, 1758) (Coleoptera: Coccinellidae), Hippodamia variegata (Goeze, 1777) (Coleoptera: Coccinellidae), Coccinella septempunctata (Linnaeus,1758) (Coleoptera: Coccinellidae), Scymnus rubromaculatus (Goeze, 1777), Loraphodius suarius (Falderman, 1835) (Coleoptera: Aphodiidae), Drasterius bimaculatus (Rossi, 1790) (Coleoptera: Elateridae), Hermaeophaga (=Orthocrepis) ruficollis (Lucas, 1849) (Coleoptera: Chrysomelidae), Bangasternus orientalis (Capiomont, 1873) (Coleoptera: Curculionidae), Aulacobaris coerulescens (Scopoli, 1763) (Coleoptera: Curculionidae), Capnodis carbonaria (Klug, 1829) (Coleoptera: Buprestidae), Tentyria euphratica (Girard 1966) (Coleoptera: Tenebrionidae), Malachius rubidus (Erichson, 1840) (Coleoptera: Malachiidae), Piezodorus lituratus (Fabricius, 1794) (Hemiptera: Pentatomidae), Liorhyssus hyalinus (Fabricius, 1794) (Hemiptera: Rhopalidae), Dolycoris baccarum (Linnaeus, 1758) (Heteroptera,: Pentatomidae), Eurygaster integriceps (Puton, 1881) (Hemiptera: Scutelleridae), Centrocoris volxemi (Puton, 1878), (Hemiptera: Coreidae), Geocoris luridus (Fieber, 1844) (Heteroptera: Lygaeidae), Chrysoperla carnea (Stephens, 1836) (Neuroptera: Chrysopidae) and Schistocerca gregaria (Forskol, 1775) (Orthoptera: Acrididae). The results revealed that burlap sack and corrugated cardboard artificial winter shelters can be used to monitor harmful and beneficial insect fauna overwintering in fruit orchards. The results provide empirical information on the existence of overwintering insect species in pistachio orchards. Thus, integrated pest management strategies should be developed for the pistachio orchards in the study area based on these results.

Key Words: Pistachio, Insect fauna, Biodiversity, Euphrates, Overwintering

\section{öz}

Bu çalışma, Orta Fırat Vadisi'ndeki antepfıstığı bahçelerinde yapay kışlama barınakları kullanılarak kışlayan böcek biyoçeşitliliğinin belirlenmesi amacıyla 2017 ve 2018 yıllarında yürütülmüştür. Yapay kışlama barınakları Şehirbağı, Karabaş, Meyanca, Baraj ve Ekenek lokasyonlarında birer antepfıstığı bahçesinde kurulmuştur. Bu amaçla Eylül-Ocak ayları arasında her bahçeden seçilen on ağaçtan beşinin gövdesine telis çuvalı, beşine de oluklu karton mukavva sarılmıştır. Çalışma sonucunda 4 takıma ait 15 familyadan toplam 20 böcek türünün Orta Fırat Vadisi'ndeki antepfıstığı bahçelerinde kışı geçirdiği belirlenmiştir. Bu türler; 
Oenopia conglobata (Linnaeus, 1758) (Coleoptera: Coccinellidae), Hippodamia variegata (Goeze, 1777) (Coleoptera: Coccinellidae), Coccinella septempunctata (Linnaeus,1758) (Coleoptera: Coccinellidae), Scymnus rubromaculatus (Goeze, 1777), Loraphodius suarius (Falderman, 1835) (Coleoptera: Aphodiidae), Drasterius bimaculatus (Rossi, 1790) (Coleoptera: Elateridae), Hermaeophaga (=Orthocrepis) ruficollis (Lucas, 1849) (Coleoptera: Chrysomelidae), Bangasternus orientalis (Capiomont, 1873) (Coleoptera: Curculionidae), Aulacobaris coerulescens (Scopoli, 1763) (Coleoptera: Curculionidae), Capnodis carbonaria (Klug, 1829) (Coleoptera: Buprestidae), Tentyria euphratica (Girard, 1966) (Coleoptera: Tenebrionidae), Malachius rubidus (Erichson, 1840) (Coleoptera: Malachiidae), Piezodorus lituratus (Fabricius, 1794) (Hemiptera: Pentatomidae), Liorhyssus hyalinus (Fabricius, 1794) (Hemiptera: Rhopalidae), Dolycoris baccarum (Linnaeus, 1758) (Heteroptera,: Pentatomidae), Eurygaster integriceps (Puton, 1881) (Hemiptera: Scutelleridae), Centrocoris volxemi (Puton, 1878), (Hemiptera: Coreidae), Geocoris luridus (Fieber, 1844) (Heteroptera: Lygaeidae), Chrysoperla carnea (Stephens, 1836) (Neuroptera: Chrysopidae) ve Schistocerca gregaria (Forskol, 1775) (Orthoptera: Acrididae). Çalışma, meyve bahçelerinde kışlayan faydalı ve zararlı böcek faunasının yapay kışlama barınaklarıyla belirlenebileceğini ortaya koymuştur. Sonuç olarak, antepfıstığı bahçelerinde kışlayan böcek türleri belirlenmiş olup hem faydalıların korunması hem de zararılırın entegre mücadeleleri konusunda stratejiler geliştirilmelidir.

Anahtar Kelimeler: Antepfıstığı, Böcek faunası, Biyoçeşitlilik, Fırat, Kışlama

\section{Introduction}

Pistachio, Pistacia vera L. (Anacardiaceae) is a cash crop that grows between $30-45^{\circ}$ parallels of the northern and southern hemispheres of the world (Tekin et al., 2001). Pistachio was first cultivated in the south-eastern Anatolia during The Hittite Era and then spread to Spain, Italy, Sicily, Southern France and North Africa in the Mediterranean basin. Furthermore, it has been reported that the fruits are cultivated in Iran, Afghanistan and India where wild species of pistachio are found (Özbek, 1978).

Turkey is an important producer of pistachio nuts. Turkey is the third biggest producer of pistachio in the world after Iran and USA (FAO, 2021). Southeastern Anatolia region, including Middle Euphrates Valley in Şanlıurfa Province, which supplies $\sim 90 \%$ of the pistachio production of the country (TUIK, 2021). The Middle Euphrates Valley has a special role in pistachio cultivation in Turkey.

There are numerous pests infesting pistachio orchards, which negatively affect its production. A large number of harmful and beneficial insect species have been reported from pistachio orchards and some of the reported harmful insect species cause significant economic damages (Mart et al., 1995). Günaydın (1978) identified 22 insect species from pistachio orchards in southeastern Anatolia and reported Chaetoptelius vestitus (Mulsant \& Rey, 1861) (Coleoptera: Scolytidae), Kermania pistaciella Amsel (Lepidoptera: Tineidae), Idiocerinus stali Fleb.
(Hemiptera: Cicadellidae) and Megastigmus pistaciae Walker (Hymenoptera: Torymidae) as important harmful species.

In another study, 70 harmful insects species belonging to 33 families in 7 orders, and 47 beneficial insect species belonging to 17 families in 4 orders were reported from pistachio orchards in Southeastern Anatolia region along with 3 harmful mite species (Bolu, 2002). In addition, many beneficial insect species as predators or parasitoids have been identified from pistachio orchards as Bolu (2004) identified 22 predatory coccinellid species in pistachio orchards of Southeastern Anatolia region of the country.

Some of arthropods spend winter in the orchards. However, limited studies have been conducted on overwintering insects in pistachio orchards in Turkey (Mamay et al., 2020). The Araneae order was the most caught with a rate of 99.15\% in the Arachnida class and the Coleoptera order was the most caught with a rate of $43.03 \%$ in the Insecta class in the study to determine the overwintering Arthropod fauna in cherry orchards in Izmir and Manisa in 1999-2001(Tezcan et al., 2006).

Yanık et al. (2011) collected Oenopia conglobata L. (Coleoptera: Coccinellidae), Piocoris luridus Fieb. (Hemiptera: Lygaeidae), Spiders, Hippodamia variegata (Goeze) (Coleptera: Cocinellidae), Deraeocoris pallens Reuther (Hemiptera: Miridae) and pistachio psylla, Agonoscena pistaciae Burck. and Laut. (Hemiptera: Psyllidae) from overwintering 
shelters in almond orchards in Şanlıurfa Province, Turkey. In the same study, researchers determined that $D$. pallens emerged first from hibernation and the spiders completed their emergence by late April.

Pistachio is a cash crop and ranks first in terms of economic importance in Southeastern Anatolian region, including the Middle Euphrates Valley in Şanlıurfa province. However, no study has reported overwintering insect fauna from the pistachio orchards in the region. This study determined overwintering harmful and beneficial insect biodiversity by artificial overwintering shelters in pistachio orchards of the Euphrates Valley in Şanlıurfa province of Turkey. The results will provide empirical information for the integrated pest management of the identified species from the region.

\section{Materials and Methods}

This study was conducted in pistachio orchards of Middle Euphrates Valley in Şanlıurfa province of Turkey from September 2017 to February 2018 including winter season. Five pistachio orchards were selected in five locations, including
Şehirbağı, Karabaş, Meyanca, Baraj and Ekenek locations in the province. The characteristics of the orchards selected for the study are given in Table 1. The orchards in Şehirbağı, Karabaş and Baraj irrigated with a drip irrigation system while there is no irrigation in Meyanca and Ekenek. In addition, plant pattern in Şehirbağı, Karabaş and Baraj was generally composed of only pistachios while in Meyanca and Ekenek barley and lentil were grown along with pistachios were grown in large areas.

Şanliurfa is located in Southeastern Anatolia region, Turkey. Summers are hot and dry with temperatures $>30^{\circ} \mathrm{C}$. Spring and autumn seasons are generally mild; however, sudden heat and cold episodes are frequently observed in the region.

The main materials used in the study were, linen sacks and corrugated cardboards set up as overwintering shelters for harmful and beneficial insects in pistachio orchards. In addition, a mouth aspirator, 70\% alcohol, Eppendorf tubes, brushes of various thicknesses, transparent polyethylene bags, a GPS tracking device (or tracker), plastic jars and other laboratory materials were used.

Table 1. Background information on the selected pistachio orchards for the study in Middle Euphrates Valley, Şanlıurfa province during 2017-2018 years

\begin{tabular}{|c|c|c|c|c|c|}
\hline Locations & Coordinates & $\begin{array}{l}\text { Area } \\
\left(\mathrm{m}^{2}\right)\end{array}$ & Altitude (m) & $\begin{array}{c}\text { Age } \\
\text { (year) }\end{array}$ & Variety \\
\hline Şehirbağı & $\begin{array}{l}37^{0} 14^{\prime} 31.956^{\prime \prime} \mathrm{N} \\
37^{0} 57^{\prime} 45.2442^{\prime \prime} \mathrm{E}\end{array}$ & 12.000 & 355 & 35 & Uzun, Kırmızı \\
\hline Karabaş & $\begin{array}{l}37^{0} 6^{\prime} 39.9456^{\prime \prime} \mathrm{N} \\
38^{\circ} 0^{\prime} 52.416^{\prime \prime} \mathrm{E}\end{array}$ & 25.000 & 631 & 25 & Uzun, Kırmızı \\
\hline Baraj & $\begin{array}{l}37^{0} 5^{\prime} 43.4148^{\prime \prime} \mathrm{N} \\
37^{0} 52^{\prime} 1.7292^{\prime \prime} \mathrm{E}\end{array}$ & 15.000 & 360 & 40 & Uzun, Kırmızı \\
\hline Ekenek & $\begin{array}{l}37^{0} 8^{\prime} 16.2414^{\prime \prime} \mathrm{N} \\
38^{0} 10^{\prime} 18.84^{\prime \prime} \mathrm{E}\end{array}$ & 30.000 & 700 & 40 & Uzun, Kırmızı \\
\hline Meyanca & $\begin{array}{l}37^{0} 8^{\prime} 43.569^{\prime \prime} \mathrm{N} \\
38^{\circ} 8^{\prime} 45.5922^{\prime \prime} \mathrm{E}\end{array}$ & 40.000 & 681 & 35 & Uzun, Kırmızı \\
\hline
\end{tabular}

Artificial overwintering shelter traps were established in the selected orchards. For this purpose, ten trees were selected within each orchard and five of these were covered with a burlap sacks and the remaining five were covered with a corrugated cardboard (Figure 1). The burlap sack and corrugated cardboards were wrapped around the tree stems to create overwintering habitats through September to end of January (Mamay et al., 2020). Insects were collected from artificial shelters at the end of January before emerging from overwintering. 
Collected insect species were grouped and counted according to their taxonomy. Then, these species were appropriately preserved, tagged and diagnosed by subject experts.
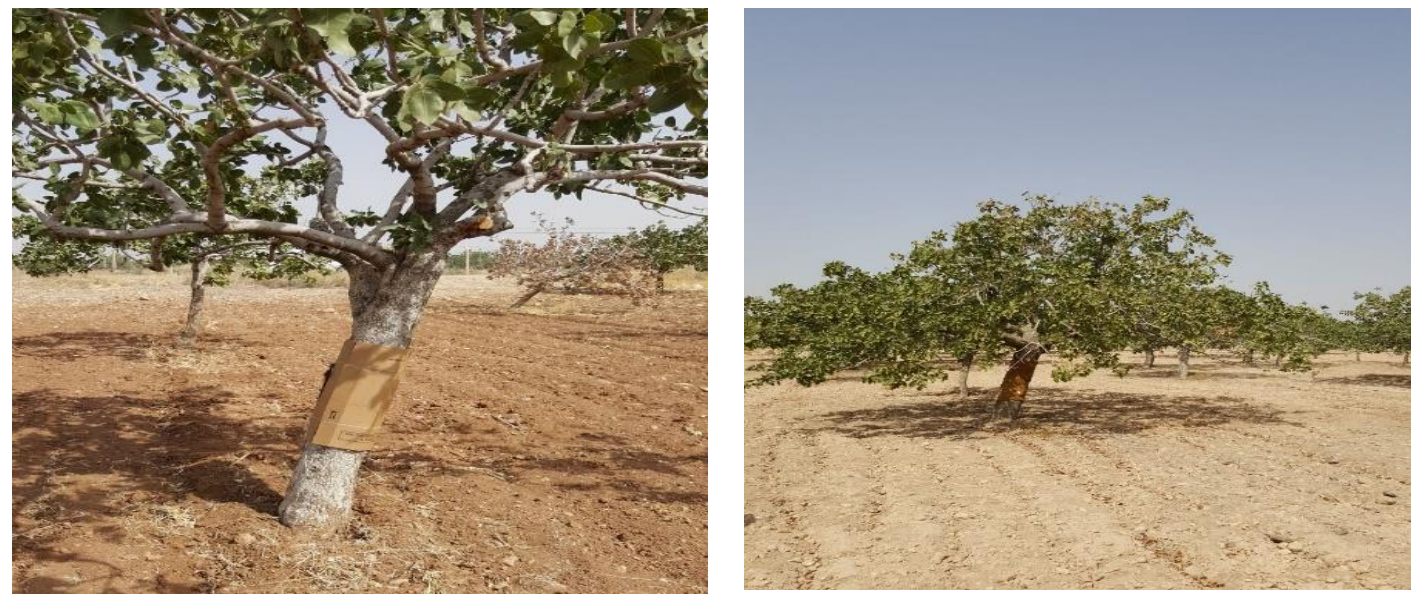

Figure 1. Artificial overwintering shelters established on pistachio trees.

\section{Results and Discussion}

Twenty insect species belonging to 15 families in 4 orders were recorded (Table 2).
The identified species belonged to Coleoptera, Hemiptera, Neuroptera and Orthoptera orders.

Table 2. Insect biodiversity overwintered in pistachio orchards of the Middle Euphrates Valley in Şanlıurfa province during 2017-2018.

\begin{tabular}{|c|c|c|c|c|c|c|c|c|c|c|c|c|}
\hline \multirow{2}{*}{ Order } & \multirow{2}{*}{ Family } & \multirow{2}{*}{ Species } & \multicolumn{2}{|c|}{ Meyanca } & \multicolumn{2}{|c|}{ Karabaş } & \multicolumn{2}{|c|}{ Baraj } & \multicolumn{2}{|c|}{ Bağlarbaşı } & \multicolumn{2}{|c|}{ Ekenek } \\
\hline & & & BS & $\mathrm{CC}$ & BS & $\mathrm{CC}$ & BS & $\mathrm{CC}$ & BS & $\mathrm{CC}$ & BS & $\mathrm{CC}$ \\
\hline \multirow{12}{*}{ Coleoptera } & Tenebrionidae & Tentyria euphratica & & & 1 & & & & 3 & 3 & 1 & \\
\hline & \multirow{4}{*}{ Coccinellidae } & Hippodamia variegata & 7 & 20 & & & & 10 & 2 & & & \\
\hline & & Oenopia conglobata & 192 & 380 & 17 & 88 & 12 & 229 & 34 & 134 & 210 & 194 \\
\hline & & Coccinella septempunctata & & & & & & 2 & & & 1 & \\
\hline & & Scymnus rubromaculatus & 5 & 10 & & & & 8 & & & & 3 \\
\hline & Elateridae & Drasterius bimaculatus & 1 & & & & & & & & & \\
\hline & Buprestidae & Capnodis carbonaria & & & & & 1 & 2 & & & & \\
\hline & Chrysomelida & Hermaeophaga ruficallis & & 5 & & & & & & & 5 & 3 \\
\hline & \multirow{2}{*}{ Curculionidae } & Bangasternus orientalis & & & & 2 & & & & & & 3 \\
\hline & & Aulacobaris coerulescens & & & 1 & & & & & & & \\
\hline & Scarabaeidae & Loraphodius suarius & & & 3 & & 5 & & & 1 & & \\
\hline & Malachidae & Malachius rubidus & & & 1 & & & & & & & \\
\hline \multirow{6}{*}{ Hemiptera } & \multirow{2}{*}{ Pentatomidae } & Piezodorus lituratus & 6 & 7 & & & 1 & 1 & & & 7 & 3 \\
\hline & & Dolycoris baccarum & 5 & 3 & & & & & & & 2 & 3 \\
\hline & Scutelleridae & Eurygaster integriceps & 1 & 2 & & & & & & & 3 & 3 \\
\hline & Lygaeidae & Geocoris luridus & & 52 & & 6 & & & 3 & 1 & 3 & 24 \\
\hline & Coreidae & Centrocoris volxemi & 3 & 4 & & & & & & & & 5 \\
\hline & Rhopolidae & Liorhyssus hyalinus & & & & 2 & & & & & & \\
\hline Neuroptera & Chrysopidae & Chrysoperla carnea & 5 & 8 & 11 & 3 & 4 & 27 & 27 & 52 & 13 & 5 \\
\hline Orthoptera & Acrididae & Schistocerca gregaria & 15 & & & 1 & 1 & & & & & \\
\hline
\end{tabular}

BS: Burlap Sack,

CC: Corrugated Cardboard

Coleoptera was the most frequently observed order in pistachio orchards. Insects mostly preferred corrugated cardboard for wintering.
Nevertheless, there is no difference among the number of species trapped by burlap sack and cardboard (Table 2). Similarly, Yanık et al. (2011) 
noted many natural enemies and several pests on wild almond located on the border of pistachio orchards caught by corrugated cardboard during winter season.

In addition, it has been determined that the number of species in Meyanca and Ekenek locations were higher than those of other locations since the agronomic practices in these orchards were not properly opted.

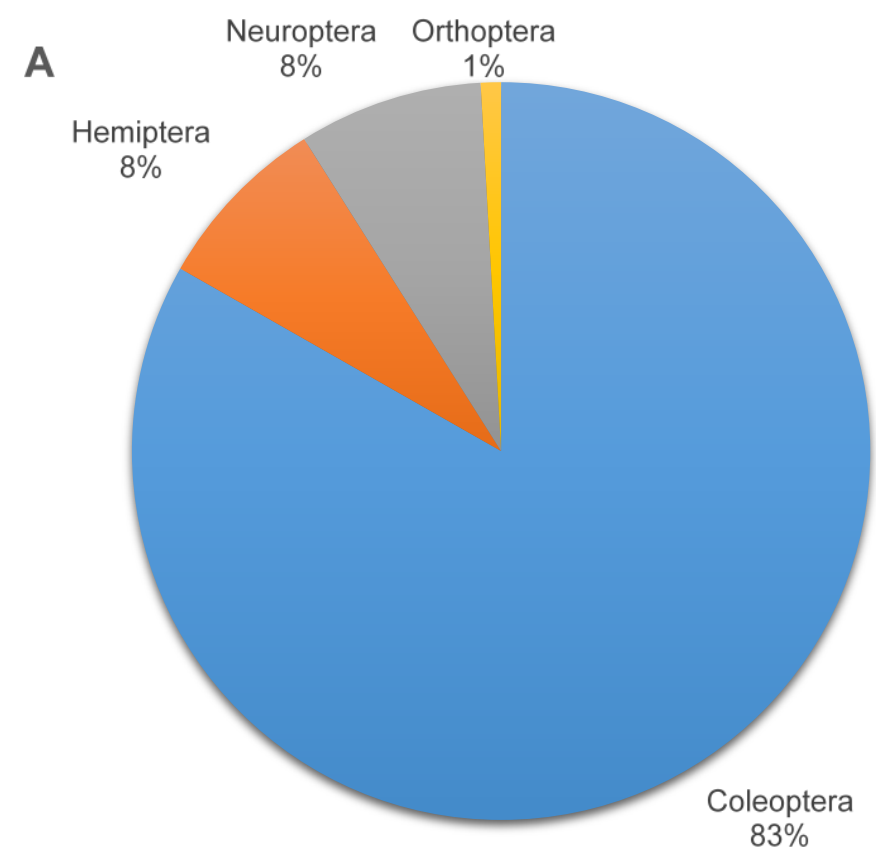

B

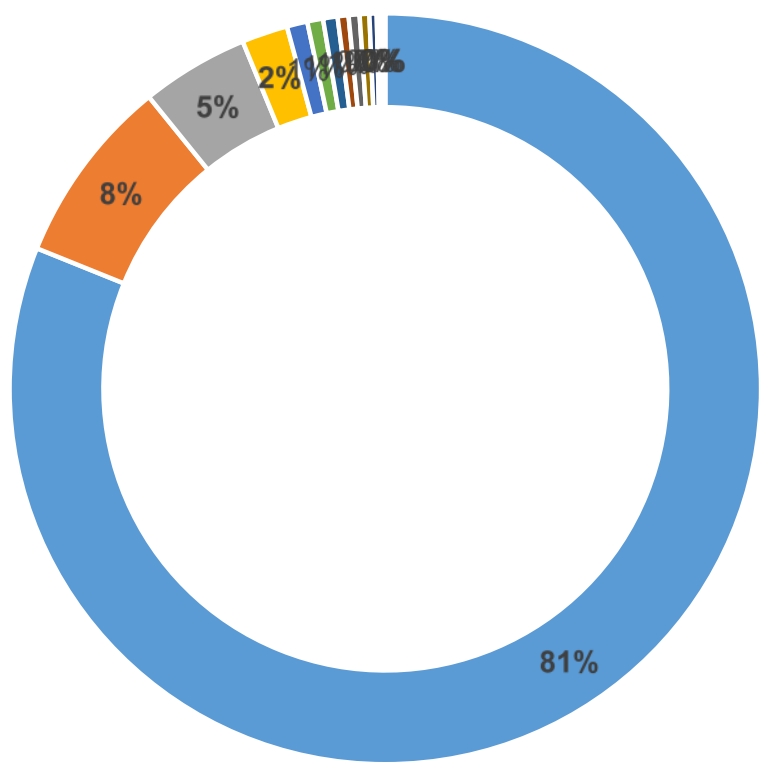

$\begin{array}{llll}\text { - Coccinellidae } & \text { - Chrysopidae } & \text { - Lygaeidae } & \text { - Pentatomidae } \\ \text { - Acrididae } & \text { - Chrysomelida } & \text { - Coreidae } & \text { - Scarabaeidae } \\ \text { - Scutelleridae } & \text { - Tenebrionidae } & \text { - Curculionidae } & \text { " Buprestidae } \\ \text { - Rhopolidae } & \text { - Elateridae } & \text { " Malachidae } & \end{array}$

Figure 2. Insect biodiversity based on orders (A) and Families (B) overwintered in pistachio orchards of the Middle Euphrates Valley in Şanlıurfa province during 2017-2018.

Coleoptera preferred overwintering shelters with 1599 individuals of 12 species belonging to 8 families and had $83 \%$ share in the overall insect biodiversity (Figure 2). The species in 
Coccinellidae family belonging Coleoptera were the most common and overwintered in corrugated cardboards. Similarly, $O$. conglobata with 1490 individuals was the most abundant species (Figure 3). Supporting this result, Mamay and Şimşek (2017) reported that $O$. conglobata is one of the important natural enemies of insect pests in pistachio orchards. Mehrnejad (2020) reported that Polydrosus davatchii Hoffman, Chaetoptelius vestitus (Mulsant \& Rey, 1861), Capnodis cariosa Hauseri and Calchaenesthes pistacivora Holzschuh from Coleoptera order in pistachio orchards of Iran. Similarly, Mamay and Şimşek (2017) noted many natural enemies belonging to Coleoptera order in pistachio orchards of Southeastern Anatolia, including $O$. conglobata, Coccinella septempunctata L., Hyperaspis quadrimaculata Redt., Pharoscymnus pharoides Marseul, Hippodamia variegata Goeze, Scymnus spp. and Stethorus gilvifrons Muls.

Hemiptera was the second most common overwintered order in pistachio orchards with 6 species, 150 individuals and $8 \%$ share in the recorded biodiversity (Table2; Figure 1). Geocoris luridus from Lygaeidae family preferred to overwinter in artificial corrugated cardboard shelters like Coccinellidae species, while there were no differences between burlap and corrugated cardboard traps in terms of preferences of other species. Earlier studies found G. luridus as widespread predator in pistachio orchards of Turkey (Şimşek \& Bolu, 2016; Mamay \& Şimşek, 2017)

Another important order, Neuroptera, densely overwintered in pistachio orchards of the studied locations. Although C. carnea was the only species in Neuroptera identified in artificial overwintering shelters, it was more than the total individual number of 6 species in the order Hemiptera with 155 individuals (Figure 2). The number of $C$. carnea individuals in corrugated cardboards was higher in some locations, in general, there was no significant difference in wintering shelter selection. Studies conducted in the same region have reported that $C$. carnea is widely found in both pistachio orchards and other fruit plantations (Şimşek \& Bolu, 2016; Mamay et al., 2018).

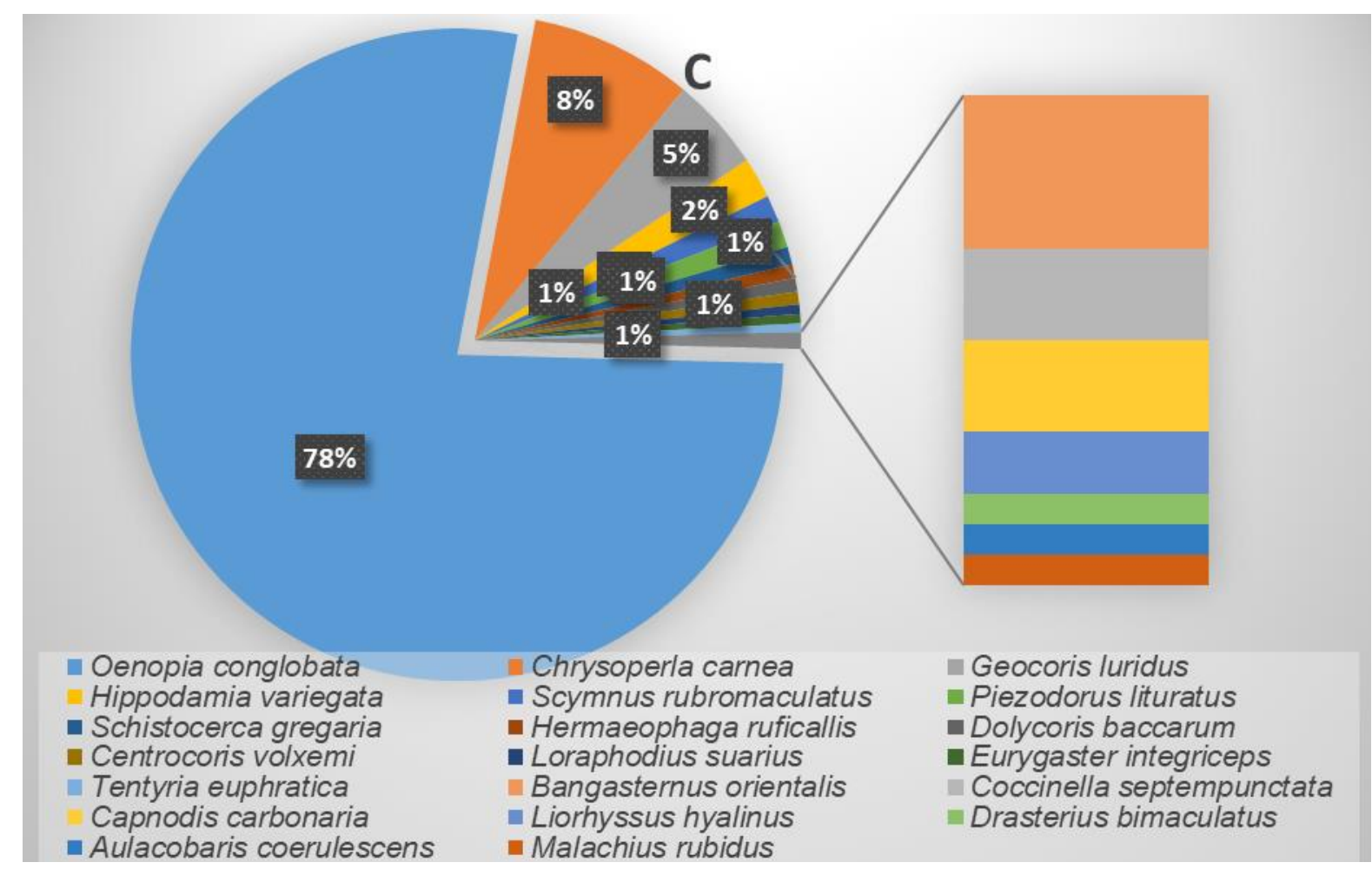

Figure 3. Insect species ratio overwintered in pistachio orchards of the Middle Euphrates Valley in Şanlıurfa province during 2017-2018. 
It is worth mentioning that density of predatory species in Meyanca and Ekenek orchards was higher than other locations. This situation is attributed to the fact that these orchards were neglected, and pesticides were not applied for pest control. It is thought that the grain pest $P$. luridus, $D$. baccarum and $E$. integriceps, which were detected in Meyanca and Ekenek locations, came from the barley and lentil fields nearby. Many studies have reported that aforementioned pests cause significantly damage to red lentil, wheat and barley fields (Mutlu et al., 2016; Mutlu et al., 2018a; Mutlu et al., 2018b). Since plant pattern in Şehirbağı, Karabaş and Baraj was generally composed of only pistachios while in Meyanca and Ekenek barley and lentil along with pistachios were grown in large areas. Moreover, the orchards in Şehirbağı, Karabaş and Baraj irrigated with a drip irrigation system while there is no irrigation in Meyanca and Ekenek. The aforementioned agricultural style and crop pattern are thought to have an impact on insect biodiversity.

Among the species trapped in overwintering shelters, $B$. orientalis, $A$. coerulescens, $H$. ruficollis and $L$. suarius were identified for the first time from the Şanlıurfa fauna.

\section{Conclusion}

This study revealed overwintering harmful and beneficial insect biodiversity in pistachio orchards of the Middle Euphrates Valley in Şanlıurfa province, Turkey. It was revealed that burlap sack and corrugated cardboard artificial winter shelters could be used to monitor harmful and beneficial insect fauna in fruit orchards.

Artificial wintering shelters can be used as mechanical control strategy by collecting and eliminating overwintering pests. Furthermore, allowing harmful pests to spend winter in these shelters would increase the density of beneficial insects. For example, these artificial overwintering shelters will contribute towards the success of mass rearing and release of $O$. conglobata in the biological control of $A$. pistaciae, which is a key pest in pistachio orchards (Mamay \& Mutlu, 2019; Mamay \& Şimşek, 2017).

With this study, it was determined that beneficial insect biodiversity was higher in areas where no pesticides are applied. For this reason, it is important to educate farmers that unnecessary and untimely spraying damages natural enemies. Therefore, chemical control should be preferred last and only specific and selective insecticides should be used when necessary. The overwintering artificial shelters can be used both for the control of pests and for the increasing beneficial insect populations.

\section{Acknowledgement}

This manuscript a part of Yeliz Sabuncu Master thesis. The authors would like to thank Dr. Paride Dioli for identifying the species belonging to Rhopalidae and Coreidae families, Dr. Stefano Ziani for identifying the species of Scarabeidae family, Dr. Rob Westwerdujin for identifying species of Malachidae family, Dr. Boris Korotyaev for identifying the species of Curculionidae family, Dr. Bekir Keskin for identifying the species of Tenebrionidae family and Dr. Ali Gök for identifying the species of Chrysomelidae family. The authors extend their sincerest thanks to Shahid Farooq (Harran University, csfa2006@gmail.com) for linguistic editing.

Conflict of Interest: The authors declare that they have no conflict of interest.

Author Contributions: MM designed the study. YS carried out the experiments. MM and iÖ evaluated the data. MM, YS and IÖ wrote the manuscript. All authors read and approved the final manuscript.

\section{References}

Bolu, H. (2002). Investigations on the fauna of insects and mites in pistachio areas in South Eastern Anatolia Region of Turkey. Turkish Journal of Entomology, 26(3), 197-208.

Bolu, H. (2004). Coccinellidae species, their distribution 
areas and their impact on population fluctuations of Agonoscena pistaciae at Pistachio orchards in Southeastern Anatolia Region in Turkey. Plant Protection Bulletin, 44(1-4), 69-77.

FAO. (2021). Food and Agriculture Organisation of the United Nations pistachio statistics. http://www.fao.org/faostat/en/\#data/QC

Günaydın, T. (1978). Güneydoğu Anadolu Bölgesi'nde antepfıstıklarında zarar yapan böcek türleri, tanımları, yayılışları ve ekonomik önemleri üzerinde araştırmalar. (Basılmamış Uzmanlık Tezi. EÜ Zir. Fak. Bit. Kor. Böl.). Bornova, Izmir, 106. Ege University.

Mamay, M., \& Mutlu, Ç. (2019). Optimizing container size and rearing density for rapid and economic mass rearing of Oenopia conglobata (Linnaeus, 1758) (Coleoptera: Coccinellidae). Turkish Journal of Entomology, 43(4), 395-408. https://doi.org/10.16970/entoted.562724

Mamay, M, \& Şimşek, E. (2017). Harmful and Beneficial Insect Biodiversity in Pistachio Orchards (Pistacia vera L.) in Southeastern Anatolia Region of Turkey. Symposium on EuroAsian Biodiversity (SEAB-2017), 32.

https://elib.bsu.by/bitstream/123456789/179927/1/ p67.pdf

Mamay, M., Özgen, İ., Danışman, T., \& Sabuncu, Y. (2020). Overwintering spider biodiversity in pistachio orchards of the Euphrates Valley in Turkey (Arachnida: Araneae). SERKET, 17(3), 230-236.

Mamay, M., Özgen, I., Demirer, B., \& Gümüş, H. (2018). Determination of Beneficial and Pest Insect Fauna in Student Farm of Harran University Agricultural Faculty Harran Üniversitesi Ziraat Fakültesi Öğrenci Uygulama Çiftliğindeki Faydalı v e Zararlı Böcek Faunasını $\mathrm{n}$ Belirlenmesi. $1^{\text {st }}$ International GAP Agriculture and Livestock Congress (UGAP-2018), 739-742.

Mart, C., Erkılıç, L., Bolu, H., Uygun, N., \& Altın, M. (1995). General review on the injurious and beneficial species and pest control methods used in pistachio orchards of Turkey. Acta Horticulture, First International Symposium on Pistachio Nut, 20-24 September 1994, 379-386.

Mehrnejad, M. R. (2020). Arthropod pests of pistachios, their natural enemies and management. Plant Protection Science, 56(4), 231-260. https://doi.org/10.17221/63/2019-PPS

Mutlu, Ç., Karaca, V., Eren, S., Buyuk, M., Gozuacik, C., Duman, M., Bayram, Y., Bolu, H., \& Kutuk, H. (2016). Chalky spot damage caused by stink bugs on red lentil seeds in Southeast Anatolia Region, Turkey. Legume Research, 39(4), 623-629. https://doi.org/10.18805/Ir.v0iOF.9437

Mutlu, C., Buyuk, M., Eren, S., Karaca, V., Duman, M., \& Bayram, Y. (2018a). Management of the Stink Bugs Dolycoris baccarum (L.) and Piezodorus lituratus (F.) (Hemiptera: Pentatomidae), and Chalky Spot Damage on Red Lentil in Southeast Anatolia Region, Turkey. Journal of the Kansas Entomological Society, 91(1), 40-50. https://doi.org/10.2317/0022-856791.1.40

Mutlu, Ç., Öğreten, A., Karaca, V., Büyük, M., \& Bayram, Y. (2018b). Efficacy of deltamethrin against Dolycoris baccarum L. and Piezodorus lituratus (F.) harmfull on red lentil in Turkey. Harran Agricultural and Food Sciience, 22(2), 179-185. https://doi.org/10.29050/harranziraat.338408

Özbek, S. (1978). Özel Meyvecilik. Çukurova University Agricultural Faculty.

Şimşek, A., \& Bolu, H. (2016). Diyarbakır ili Antep fıstığı ( Pistacia vera L.) alanlarındaki yararlı böcek faunasının belirlenmesi. Bitki Koruma Bülteni, 56(3), 1-30. https://doi.org/10.16955/bkb.56653

Tekin, H., Arpacı, S., Atlı, H. S., Açar, I., Karadağ, S., Yükçeken, Y., \& Yaman, A. (2001). Antepfıstığı Yetiştiriciliği. Pistachio Research Institute Gaziantep.

Tezcan, S., Keskin, B., \& Gülperçin, N. (2006). An evaluation on overwintering trap fauna of organic cherry orchards of İzmir and Manisa Provinces. 3.Organik Tarım Sempozyumu Bildirileri, 112.

TUIK. (2021). Turkish Statistical Institute pistachio statistics. http://tuik.gov.tr/Start.do.

Yanik, E., Unlu, L., \& Yucel, A. (2011). The Phenology of Em ergence From A rtificial Overwintering Sites by Predatory $A$ rthropods in Pistachio $O$ rchards and $A$ djacent $\mathrm{H}$ abitats. Ekoloji, 20(78), 1-6. https://doi.org/10.5053/ekoloji.2011.781. 